\title{
Fusioner - Danske Gymnastik- og Idrætsforeninger \\ - Danmarks Idræts-Forbund. Et historisk essay
}

\author{
Af Jørn Hansen
}

I 1992 fusionerede De Danske SkytteGymnastik- og Idrætsforeninger med De Danske Gymnastik og Ungdomsforeninger. Den nye organisation fik navnet Danske Gymnastik- og Idrætsforeninger. Selvom skytterne fik en særlig status i den nye organisation indgik det national-patriotiske skyttebegreb ikke i den nye hovedorganisation. Men der skulle gå 131 år før man fandt det for odiøst at lade ordet »skytte « indgå $\mathrm{i}$ en organisation, hvis væsentligste opgave blev at organisere den folkelige idræt. Sammenlægningen blev kraftig debatteret, men egentlig ikke mødt med synderlig stor modstand af de to hovedorganisationers medlemmer.

Året efter skete en anden fusion inden for idrættens verden. Dansk Idræts-Forbund og Danmarks Olympiske Komité blev til Danmarks Idræts-Forbund. En sammenlægning, der ikke i samme grad som den ovenfor omtalte, fik pressens bevågenhed. DOK var en lille organisation, der altid havde haft tætte relationer til DIF. Og der havde aldrig været tale om et modsætningsforhold, der kunne sammenlignes med de modsætninger, der historisk havde været mellem skytter og gymnaster, og som på et tidspunkt førte til spaltningen i to folkelige organisationer.
Hvilken historie lå i sin tid bag splittelsen af skyttebevægelsen og gymnastikbevægelsen, hvorledes kan samlingsbestræbelserne opfattes, hvilken rolle har Dansk Idræts-Forbund spillet i forholdet til skytteog gymnastikbevægelserne, og hvilken rolle må de to nye organisationer formodes at komme til at spille fremover? Dette er en række af de problemer, der vil blive belyst $i$ den følgende artikel. Først følger dog en liste over de vigtigste begivenheder.

\section{De vigtigste begivenheder:}

1861 Dannelsen af De Danske Skytteforeninger.

1864 Tabet af Sønderjylland.

1871 Nederlag til Frankrig i den tyskfranske krig - håbet om generhvervelsen af Sønderjylland får lange udsigter - begyndende diskussion af DDS's rolle - gymnastikken vinder udbredelse.

1884 Den svenske gymnastik - Lings gymnastik introduceres i Danmark. Det vil sige, den gymnastikform, der udviklede sig til den folkelige gymnastik

1896 Dansk Idræts-Forbund (DIF) dannes som interesseorganisation for amatør-sporten 
1899 Dansk Gymnastik-Forbund dannes som en organisation, der vil fastholde den gamle danske gymnastik og forbinde denne med den tyske gymnastik (turnen). Der er delvis tale om en modbevægelse til den folkelige gymnastik. DGF indgår med tiden i DIF.

1905 Danmarks Olympiske Komité dannes for at sikre dansk deltagelse ved de kommende olympiske lege.

1919 De Danske Skytteforeninger bliver til De Danske Skytte- og Gymnastikforeninger (DDS\&G).

1929/30 Hovedparten af gymnasterne forlader DDS\&G og danner De Danske Gymnastikforeninger (DDG).

1930 DDS\&G reorganiseres og bliver til De Danske Skytte- Gymnastik- \& Idrætsforeninger.

1946 Dansk Firma Idræts-Forbund (DFIF) dannes.

1948 Tipsloven med støtteordninger til idrætten og kulturen indføres.

1965 DDG sammenlægges med De Danske Ungdomsforeninger og bliver til De danske Gymnastikog Ungdomsforeninger (DDGU).

1967 Idrættens Fællesråd etableres som et samarbejdsorgan for DDSG\&I, DIF, DDGU og DFIF.

1985 Team Danmark etableres.

1992 DDSG\&I og DDGU sammenlægges bliver til Danske Gymnastik- og Idrætsforeninger (DGI).

1993 DIF og DOK sammenlægges og bliver til Danmarks Idræts-Forbund (DIF).

\section{Dansk Idraet - Skyttebevagelsen}

Af ovennævnte liste fremgår, at der længe har været og stadig er flere organisationer, der varetager dansk idræts interesser. Hvorledes er det gået til at Danmark i 1994 har tre hovedorganisationer, når idrætten i Norge og Sverige næsten fra starten blev samlet $i$ et landsforbund. En udbredt forklaring har været en henvisning til den rolle som ideologiske faktorer har spillet $\mathrm{i}$ dansk idræts historie. Dette er givetvis også rigtig for visse perioder af dansk idræts historie, men desværre har denne konstatering ofte ført til en udbredt bagklog ideologisering af historieskrivningen om dansk idrætshistorie.

Der er ingen tvivl om, at vi i det 20. århundrede kan skelne mellem sportsbevægelsen og den folkelige idræt - faktisk spillede denne adskillelse en vigtig rolle $i$ samlingsbestræbelserne mellem DDSG\&I og DDGU. Mere tvivlsomt er det imidlertid, om man allerede før århundredeskiftet skarpt kunne skelne mellem sportsbevægelsen og den folkelige idræt. I det 19. århundrede var det på det ideologiske plan noget andet, der var på spil.

DDS (DDSG\&I) startede i 1861 efter engelsk forbillede som en national bevægelse med det formål at styrke landets forsvar. Skydeøvelser og skydestævner var det primære, men legemsøvelser som supplement vandt hurtig udbredelse; med tiden blev legemsøvelser ligestillet med skydningen. Fra begyndelsen var bevægelsen tæt knyttet til militæret og staten, der støttede bevægelsen $\varnothing$ konomisk. Efter tabet af Sønderjylland i 1864 forstærkedes det nationale islæt i skyttebevægelsen. I skyttebevægelsens etableringsfase opereredes der ikke med en skarp adskillelse af gymnastik, leg og boldspil. Flere steder omfattede legems$\emptyset$ velser såvel gymnastik som boldspil og anden leg, andre steder spillede exercitsen en rolle. Flere og heriblandt en række militærofficerer var fortalere for at opfatte såvel skydning som legemsøvelser som hørende til de frie idrætter. 
Efter Frankrigs nederlag til Tyskland i 1871 blev det klart, at generhvervelsen af Sønderjylland ved hjælp af internationale alliancer ville have lange udsigter. Preussen stod nu i spidsen for det tyske kejserrige. På denne baggrund blev skytternes national-patriotiske træning lidt uvirkelig. Præmieskydning og gymnastikken blev i højere grad til aktiviteter.

\section{Dansk Idrat - Gymnastikken}

I 1884 forevistes den lingske gymnastik ved indvielsen af Vallekildes Højskoles nye $\emptyset$ velseshus. Gymnastikformen vandt hurtig fodfæste og fik sine varmeste fortalere blandt personer i højskolebevægelsen. Den lingske gymnastik blev således knyttet til en af det 19. århundredes vigtige folkelige bevægelser. Om dette var en tilfældighed eller et udtryk for, at selve gymnastikformen var speciel folkelig får vi nok aldrig afklaret. Vigtigt var det imidlertid, at den lingske gymnastik som et nordisk foretagende blev en del af spillet om den danske bevidsthed. Denne gymnastikform blev modstillet den »gamle« (fra o. 1800) danske gymnastik, der var af mellemeuropæisk eller, som det blev sagt, tysk oprindelse.

Det var således med udgangspunkt i højskolebevægelsens nyeste gymnastikform, at man i perioden fra 1884 og frem til århundredeskiftet formulerede sig mest radikalt og afklaret om legemsøvelser og dansk idræt. Da højskolebevægelsen og dermed den lingske gymnastik samtidig fik en afgørende ideologisk betydning i kampen mod Estrups provisorielove og var med til at vinde kampen for parlamentarismen, blev den lingske gymnastik reelt til den folkelige idræt. Man kan sammenfatte det således, at den folkelige gymnastik før 1900 ikke var et mål i sig selv, men var en del af en bevægelse uden for sig selv.
Den $\emptyset$ gede bevidsthed blandt ling-gymnasterne førte nærmest til ønsket om en generel rendyrkelse af denne gymnastikform. Derfor opstod modbevægelsen, der førte til dannelsen af Dansk Gymnastik-Forbund. Fortalerne bag dette forbund var interesseret $\mathrm{i}$ at videreføre den gamle gymnastikform og forbinde den med den tyske turnen. Det var i regie af DGF, at det vi er kommet til at kende som konkurrencegymnastik især har udviklet sig. Som modbevægelse til den folkelige gymnastik kom DGF som en stærk organisation inden for DIF med tiden til at medvirke til etableringen af en begyndende modsætning mellem den folkelig idræt og DIF.

\section{Dansk Idrat - Sporten}

Udøvelsen af den engelske sport eller konkurrenceidræt vandt $\mathrm{i}$ byerne mere og mere udbredelse i 1880'erne. Fra begyndelsen var der intet modsætningsforhold mellem de, der udøvede den nye engelske legemskultur og idrætten i skyttebevægelsen. Reelt var mange af pionererne, der var med til at introducere sporten i Danmark, organiseret $\mathrm{i}$ foreninger under DDS. Dannelsen af Dansk Idræets-Forbund i 1896 var derfor ikke et forsøg på umiddelbart at afgrænse sig fra DDS, men skulle snarere ses som et udtrykt ønske om at få orden i egne rækker inden for sportsbevægelsen. Faktisk blev DDS inviteret til at deltage i det møde der førte til stiftelsen af DIF. DDS sendte dog ingen repræsentanter. DIF skulle være en organisation for amatør-sporten og den rigtige sport, der tog et legemligt udgangspunkt. DIF vendte sig således fra begyndelsen især mod cykelsportens totalisatorspil og anvendelse af maskinkraft samt hestevæddeløbene.

Reelt kom DIF først til at spille en egentlig rolle i dansk idræt i mellemkrigstiden, 
hvor sporten efterhånden havde bredt sig til de fleste mindre byer og til landområderne. DIF og DDS fungerede faktisk udmærket side om side, eneste anstødsssten for DIF var DDS's gode støtteaftaler med staten. Frem til 1929 var der ikke tale om en konflikt mellem sporten og den folkelige idræt, men i stedet tale om en konflikt inden for den folkelige idræt.

\section{Bruddet $i 1929$ \\ - to folkelige bevagelser i 1930}

Efter indførelsen af den lingske gymnastik i 1884 tillod man i DDS, at medlemmer kunne dyrke gymnastik uden at dyrke skydning, og det betød med tiden at flere og flere DDS-medlemmer udelukkende dyrkede gymnastik. Det er blevet anslået, at ca. $90 \%$ af gymnasterne omkring 1 . verdenskrig ikke dyrkede skydning.

Dette førte med tiden til en skærpet ideologisk kamp mellem skytter og gymnaster, der i første omgang førte til navneændringen i 1919 til DDS\&G. Det må formodes, at skyttebevægelsens nationale og folkelige rolle mindskedes i betydning efter 1 . verdenskrig og med genforeningen og $1 \varnothing$ sningen af det sønderjydske spørgsmål i 1920. Til gengæld kom gymnasterne i løbet af 1920'erne på det bevidsthedsmæssige plan til at formulere sig i en mere og mere »ren « folkelig udgave.

Det er lidt af et paradoks, at det var Niels Bukh, der, i ønsket om at samle den danske ungdom, kom til at spille en afgørende rolle i bruddet mellem gymnaster og skytter. Niels Bukhs meget »rene « forhold til gymnastikken blev her en afgørende vigtig faktor.

Grundet DDS\&G's oprindelseshistorie havde skytterne en $\varnothing$ konomisk særstatus i bevægelsen. En bestemt sum af statsmidlerne blev forlods tildelt skytterne, hvorefter resten blev fordelt blandt forneningerne. Dette mødte med tiden større og større modstand fra gymnasterne, der endvidere følte, at deres kontingent gik til ammunition til skytterne. Dertil kom et efterhånden tydeligt forskelligt adfærdsmønster hos skytter og gymnaster.

Gymnasterne med Niels Bukh i spidsen opfattede skytterne som personer, der anså præmieskydning og fester som det vigtigste. Især skyttefester, hvor der blev drukket tæt blev lagt for had. I stedet begyndte gymnaster enkelte steder at afholde fester uden spiritus.

Bevidstheden hos de gymnastikledere, der i 1929 talte for en sprængning af DDS\&G, var utvivlsomt høj. På det politiske plan var der en tendens til, at det nydannede DDG især kom til at stå stærkest $\mathrm{i}$ kredse, hvor den radikal-orienterede antimilitarisme var dominerende blandt de folkelige grundtvigianere. Undtagelserne var her Ribe amt og Ringkøbing amt, hvor DDG forbandtes med en decideret anti-indremissionsk bevægelse.

Da DDG i 1930 så dagens lys, var en af skytternes stærkeste kritikere Niels Bukh ikke at finde i den nye organisation. På trods af sine grundholdninger modarbejdede Niels Bukh splittelsen, fordi hans vision var ét stærkt nationalt ungdomsforbund. Splittelsen af DDS\&G førte i 1930 til en begyndende modernisering af den gamle hovedorganisation, der nu kom til at hedde DDSG\&I. Tilføjelsen af ordet idræt varslede på mange punkter de nye tendenser inden for dansk idræt. Der skulle dog gå nogle årtier før hovedmodsætningen forskubbedes til at være en modsætning mellem idræt og sport eller den folkelige idræt og Dansk Idræts-Forbund. 


\section{Folkelig idrat eller breddeidrat}

I mellemkrigstiden vandt den engelske sport større og større udbredelse inden for de folkelige organisationer. Mønsteret i de mindre byer og i landområderne blev efterhånden gymnastik om vinteren og boldspil som håndbold eller fodbold om sommeren. Skytterne blev med tiden en mere fast afgrænset gruppe. I takt med sportens udbredelse blev det nødvendigt med en ideologisk oprustning i de folkelige organisationer for at kunne afgrænse sig fra idrætten under Dansk Idræts-Forbund.

Vigtig var her betoningen af, at idrætsudøvelsen ikke måtte være et mål i sig selv. Hvis dette var tilfældet kunne begrebet det folkelige ikke knyttes til bevægelsen. En af de personer, der mest præcist formulerede sig om begrebet folkelig idræt var Jørgen Bukdahl. I en tid, hvor begrebet folkelighed indimellem antager slagordskarakter kan det måske være på sin plads, at referere Bukdahls overvejelser.

Jørgen Bukdahl formulerede blandt andet sine overvejelser i sin epilog »Dansk Idræt « til samleværket »Idræt. Vor Tids store Folkeopdrager « redigeret af $\mathrm{Kr}$. Krogshede (1943). Bukdahl skrev:

»Lad os da nu se på Idrætten paa en større Baggrund end en rent sportslig Interesse. Arkimedes sagde en Gang, at han kunne bevæge Jorden, hvis man gav ham et punkt udenfor. Punktet udenfor der giver det hele mening udover Tidsfordriv og Interesse; Idrætten har ogsaa saadan et Punkt«.

Bukdahl tog således afstand fra situationer, hvor idrætten og sporten var blevet sit eget formål, hvor interessen for det fysiske var så opslugende, at det kom til at virke forkrøblende på, hvad der havde med ånd og karakter at gøre. For eksempel idræt, hvor cykelrytteren hang over styret med tungen ud af halsen, eller hvor uhyggelige deforme kvinder beredte sig til at svømme over Oceaner. I stedet burde man tage ved lære af den måde den folkelige idræt startede på:

»Der er en Himmel over Idrætspladsen, og der er et Land udenom den. Det var dette man forstod herhjemme i (18)80'erne, da den Lingske Gymnastik blev indført som et Led i den folkelige Opdragelse og Vækkelse. Thi man var nemlig ogsaa da klar over, at en ensidig Aandsinteresse kan være ligesaa forkvaklende for et Menneske, som en ensidig Interesse for det fysiske. Legemet er Sjælens Bolig, og Mennesket er skabt i Guds Billede. Dette var Synspunktet for hine Vallekildemænd, der gav Stødet til, at den Lingske Gymnastik blev Folkegymnastikken i Danmark, det mest vidtrækkende, der endnu er sket i en Ungdomsopdragelse...Det Punkt udenfor, der netop knyttede Gymnastikken som Led til en national Helhed, var det, man kalder det folkelige «.

Jørgen Bukdahl skrev epilogen til et samleværk om dansk idræt, der behandlede såvel gymnastikken som sporten, hvor sport og idræt i Bukdahls terminologi dækkede over det samme. Den ideelle, den folkelige legemskultur var gymnastikken. Idrætten var ikke ideel:

»Jeg kunde ønske dansk Idræt noget af dette folkelige Punkt udenfor de mange Grene og de særlige Interesser omkring dem. Saa bliver Fritidssyssel lænket til Dagens Gerning, saa kan der oprettes en Harmoni mellem Legemet og Sjælens Verden $\ll$.

I vore ører kan Bukdahls udsagn i dag måske forekomme lovlig patetiske. På den anden side udtrykke Bukdahl præcist, hvad der var (og er) på spil på det ideologiske plan. I takt med at aktiviteterne i de forskel- 
lige hovedorganisationer i stadig højere grad er kommet til at ligne hinanden, er det blevet vigtigt at kunne skelne på anden led. Modsætningen blev i den anden halvdel af det 20. århundrede derfor ikke længere en ideologisk modsætning mellem gymnaster og skytter, men en ideologisk modsætning mellem folkelig idræt og sport. Ved at betone de folkelige rødder er DDSG\&I og DDGU kommet til at ligne hinanden. Vigtigere blev for disse organisationer således afgrænsningen til DIF, hvor idrætten angiveligt ikke skulle have noget punkt uden for. Om dette så er »korrekt « er og bliver vedvarende en holdningsdiskussion.

Reelt nærmede DDSG\&I og DDGU sig da også hinanden i perioden efter anden verdenskrig. Allerede i løbet af 30'erne forslog Niels Bukh flere gange en sammenlægning af DDSG\&I og DDG. Uoverensstemmelserne var dog på dette tidspunkt for store. DDSG\&I betonede forsvarviljen som det vigtigste, DDG betonede det danske sindelag som det vigtigste. Efter krigen, allerede fra 1947 var forholdet mellem de to folkelige hovedorganisationer dog normaliseret så meget, at de indgik et samarbejde om turneringer, kurser og landsstævner.

I 1965 blussede de gamle modsætninger op igen. Årsagen var DDG's sammenslutning med den grundtvigianske bevægelse De Danske Ungdomsforeninger. Dette betød påny en betoning af højskoleidéerne over for DDSG\&I's forbindelser med militæret og påståede større præmieorientering. En sidste hindring for viderførelsen af det tætte samarbejde faldt dog i 1972, da DDSG\&I sløjfede udsagnet om forsvarsviljen fra sin formålsparagraf.

Alligevel skulle der gå tyve år før det tætte samarbejde blev til en sammenlægning. Måske spillede det en vigtig rolle, at DIF ikke længere kunne opfattes som hjemstedet for eliteidrætten - hvor det jo ofte var denne eliteidræt, der var den mest udskældte af tilhængerne af den folkelige idræt. I 1984 vedtog folketinget en lov om eliteidrættens fremme og i 1985 blev Team Danmark etableret. Reelt kom dette til at betyde, at eliteidrætten med tiden blev lagt uden for DIF's regie. Selvfølgelig kom eliteudøverne fra specialforbundene under DIF, men egentlig eliteidrætspleje var ikke længere et arbejde for DIF. Det blev således klart, at DIF i højere grad fremover ville varetage breddeidrættens interesser.

Denne udvikling inden for DIF skete samtidig med at idrætsbilledet inden for DDSG\&I og DDGU blev bredere. Endnu flere idrætsaktiviteter blev fælles for de tre store hovedorganisationer. Som led i en ideolgisk oprustning formulerede Leif Mikkelsen fra DDGU i begyndelsen af 1990'erne en modsætning mellem folkelig idræt og breddeidræt. Dette skete med klar adresse til DIF, der anså dannelsen af en stor hovedorganisation som en naturlig overbygning på idrætten i 1990'erne, efter at eliteidrætten var blevet adskilt som en størrelse for sig. Som bekendt blev resultatet dannelsen af DGI i 1992, samt ihærdige bestræbelser på profileringen af den folkelige enhedsorganisation. Den nye tipslov med rigelige mængder af lotto-midler til idrættens organisationer har i høj grad medvirket til at skabe det $\varnothing$ konomiske fundament for profileringsbestræbelserne.

\section{Den folkelige ideologis aktualitet og realitet}

Som historiker må man selvfølgelig begejstres over, at diskussionen mellem DIF og DGI i høj grad indeholder historiske argumenter og i den forstand holder historien i live. Ét er imidlertid et forsøg på at beskrive, hvad folkelig idræt er ud fra spidsteore- 
tikernes formuleringer. Noget andet kunne være at forholde sig til den praksis og realitet, der præger idrætsudfoldelsen i dagligdagen. Sat på spidsen kunne man spørge, hvad er en folkelighed uden folkets medvirken. Eller sagt lidt gammeldags; uden masserne blamerer idéerne sig.

Der er ikke lavet større undersøgelser af, hvorledes folkeligheden sætter sig igennem over for medlemmerne i DGI eller for den sags skyld for medlemmerne i DIF. Få studenteropgaver har beskæftiget sig hermed og ofte kunnet påvise, at såkaldte almindelige medlemmer intet aner om deres hovedorganisations eventuelle ideologiske ståsted, ligesom en sådan heller ikke interesserer dem. Det er med denne viden in mente, at man med rette kan problematisere den patos, der nogle gange præger diskussionerne i idrættens verden. For hvad er en folkelighed, der ikke udgår fra folket, egentlig værd. Bevæger vi os hermed ikke ind i ideologiske konstruktioner som liberalisme, socialisme og ja - folkelighed?

\section{Litteratur}

Jørgen Bukdahl: Dansk Idrat. Epilog. i »Idræt, Vor Tids store Folkeopdrager« red. Kr. Krogshede. Odense 1943.

Jørn Hansen: Gymnastik og sport - det borgerlige samfund og industrisamfundet, $\mathrm{i} »$ Mellem kald og videnskab« Idrætshistorisk Årbog 1989.

Ove Korsgaard: Kampen om kroppen. København 1982.

Herbert Sander: Dansk Idrcet gennem 50 aar. København 1946 
